\title{
Folk loral Basics in the Artistic Work of Aleksandre Kazbegi
}

\author{
Eka Vardoshvili \\ Ivane Javakhishvili Tbilisi State University, Tbilisi, Georgia
}

\begin{abstract}
Aleksandre Kazbegi ${ }^{1}$ in his works uses the rich folkloric material of mountain that is reformed and revised by the creator's hand and represents the soul of mountaineers, characters and customs, their passion for personal and national freedom. In the scientific literature consider that national legend "Sleeping" is the basis of the work "Khevisberi Gocha”. Deep trace of traditional folklore is observed in the story "Elguja”. It is important that the main characters of the work Elguja and SvimonChopikashvili are real persons. The writer presented immortal face of GinjaKhuleli in the story, who was a ravine narrator. In the story recorded folk poems/scenes for customare used, funeral rumor, and mourning with dead voice. The community is a strong defender of customs. Prosecution and reconciliation with sworn enemy is expressed in an interesting way. The community discussed the issue about Elguja and SvimonChopikashvili and made a decision upon that. In the story the author describes the institute of brotherhood. The story has a political character.In the letters "Mokheves ${ }^{2}$ and their life” Aleksandre Kazbegi tells about the way of life of the mountaineers, their customs, which are afterwards generalized in his artistic works.
\end{abstract}

Keywords: works of Kazbegi, folklore of mountaineers, characters and customs of mountaineers

\section{Introduction}

Aleksandre Kazbegi is a remarkable representative of Georgian Realism. He is a successor of literary traditions of Ilia Chavchavadze.Kazbegi clearly expresses political situation of the XIX century in Georgia, in his works he demonstrates struggle of Caucasian people against Russian Tsarist autocracy. In his poetic and prose works he relies on historical facts and tries to depict the pictures of mountaineers' life, while describing of the characters he uses folkloric material.

\section{Aleksandre Kazbegi and Folk Poetry}

The first work of Al. Kazbegi,

Published in 1880 in the newspaper "Droeba", "Mokheves and their life”, has an ethnographic character. In the letter the author describes life of mountaineers, their customs and traditions and spiritual values in detail, which he afterwards generalizes in his literary works. (Vardoshvili, 2010, p. 93)

The letter was published under a pseudonym A. Mochkhubaridze and it is interesting from the viewpoint of study of folkloric material in the works of Al. Kazbegi.

The researcher M. Chikovani focuses on two issues in the letter "Al. Kazbegi-collector of the mountain poetry”: First,

Eka Vardoshvili, Doctor of Philology, Associated Professor, Tbilisi State University.

${ }^{1}$ Aleksandre Kazbegi is Khevi community bringer in Georgian literature (Khevi-ravine and also village in Kazbegi region).

${ }^{2}$ Mokheve-(in plural: Mokheves) a person residing in Khevi. 
The author has been among the Mokheves since his childhood, he was aware of their vexation and sorrow. Intimacy with the people with mountainous courageous nature made Al. Kazbegi fall in love with folklore and their performers, men and women, old and young people of his homeland, who emotionally feel every nuance of a poetic word in Kazbegi's stories and novels. And the second, Al. Kazbegi collected enthusiastically and spread the monuments of mountain poetry. In 1885 the part of his poems was published in the journal "Iveria" with the title: "Folk poems collected in Khevi by A. Mochkhubaridze”. In 1886 they were published in Tbilisi as a book "Folk poems, of Mokheves and Mokheve’ssongs".At that time Kazbegi had "Folk poems and aphorisms" ready for publishing. Except published folk poems, there are some samples of mountain poetry in manuscript format in Al. Kazbegi's archive, which the person, who had written down them, read from the stage during the speech. (Chikovani, 1952, pp. 157-158)

The works of the writer are rich not only with folkloric material, but he is also a collector and a publisher of the samples of folk poetry.

When searching for folkloric basics in the works of Kazbegi we should pay a special attention to the fact that in spring of 1871 the author, who had returned from Russia several months before, becomes a shepherd and till 1879 he lived with the other shepherds in the mountains. He writes about this period of his life in the autobiographical story "Memories of the shepherd".

In 18... I decided to become a shepherd and with the help of this trade to walk over the mountains and then lowlands, to get acquainted with the people and to feel the life of the shepherd full of fear and pleasure, which accompanies him all the time.Of course, everybody, absolutely everybody laughed at my first steps, because they were saying that it is no proper conduct for the nobleman and the son of the reputable man to become a shepherd, but I had my own goal, my wish and it was so strong that I didn't listen to anybody's advice: I wanted to see people, wished to know about their wishes, to live their lives, to feel their demands and troubles the workers have, and nothing could keep me at home. I've achieved my goal, I became close with them, got acquainted with them, with whom I wanted to become close friends and get acquainted. (Kazbegi, 1976, p. 212)

The goal of the writer was to get to know the life of the mountaineers, to comprehend the depth of their souls. Since 1879 Al. Kazbegi moves to Tbilisi and begins writing his prose works.

"Tsitska" was his first story which is dated back to 1880, in 1885 Kazbegi writes a story "Priest", which is his last artistic work. His creative process is not long, but is thematically diverse. Despite the fact that he is a strong national writer, his works are often compared with the prose works of V. Hugo, Prosper Merimee, G. Gryphius and others.

"Memories of the shepherd" is dated back to 1882-1883. We would like to note that autobiographical genre is characteristic for the Georgian realist writers of the 19th century.

"Memories of the shepherd" is finished in the following way,

I stop writing these letters, for what I saw and heard, how I heard and understood it, I decided to show them to you as stories and to introduce to you customs, character and rules of those people, which are the part of Georgia or they are not, and their necessary related neighbors, with whom the relation is inevitable in near future.(Kazbegi, 1976, p. 243)

Life of mountaineers described in "Memories of the shepherd" almost coincides with the story told in the ethnographical letter "Mokheves and their lives".

\section{Folklore in the Prose Works of Kazbegi}

Al. Kazbegi describes life of mountaineers in his work "Elguja”, "Father's killer", "Left-handed", "Eleonora”, “Khevisberi Gocha”, "Priest”, “Eliso”...

Kazbegi explained intimate feelings on social language. He showed the nature in connection with lives of human beings. 
In scientific literature it is considered, that the basis of the story "Khevisberi Gocha" is a legend "Sleeping", there are several versions of it. Mokheve Ginja Khuleli told this story to the author, whose character Kazbegi describes in "Elguja”. "Khevisberi Gocha” is the peak of Kazbegi's works and with artistic interpretation it is related to the soul of "Shakespeare's" realism. This story is often compared with "Mateo Falcone” of Prosper Merimee.

The historic basis of the story is the wish of Nugzar Eristavi, who lived at the end of the 16th and the beginning of the 17th centuries, to subordinate free Khevi, which resulted in strong resistance of the mountaineers.

The work starts with description of the ritual scenes connected with the wedding.

The guests entered the house full of people, where the elder people met them, blessed the bridegroom's way, led him around the hearth and seated him at the edge of the hearth with the "groomsman" and the elder person of the house. The standing people sat down and they continued their feast and sent the bowls with usual toasts.There were only men here, the women were nowhere to see. Their voices were to hear and behind the back corner of the house, they were dancing there and attracted young boys, passionately watching the beautiful women dancing Lekuri...After several minutes, the people broke up and an old woman appeared between them. All stood up and greeted the old woman, who directly came up to the "groomsman", hugged and told her: — so, my all, I entrust my little girl to you... You must take care of her, protect her, you must embitter those who embitter her! (Kazbegi, 1976, pp. 253-254)

In the story Mokheve Gugua gets married with Dzidzia and their groomsman is Onise, the only son of Khevisberi Gocha. Onise and Dzidzia earnestly fall in love with each other, in the story Onise is trying to avoid this feeling, but he is powerless against love, which leads to tragic ending. Khevisberi Gocha kills his son with his own hands, however, the trial acquits him and he is not charged with the betrayal of the Mokheves. After murder of his son Khevisberi Gocha goes mad. Dzidzia and Gugua die too.

The scene of "blessing" is impressively described: when the Mokheves gathered at the yard of the church to decide an important issue.

First the cross of the flag appeared from the fencing of the church and then the whole flag emerged. At the same moment the people went down on their knees and worshiped the saint. A man with long grey hair and a beard without a hat appeared at the wall... The village flags drifted away from the people, which the standard-bearers in white chokhas took to the fencing of the church and after several minutes they wrapped them at the top of the flag... The old man touched the flag and ringing of small bells was heard in total silence... Gocha touched the flag once more, then he rang the bells once more and started blessing of people crossing himself quietly, sweetly and unhurriedly. After this blessing he began to bless those who dedicated themselvesto the village and did their best for welfare of their people. And he finished his blessing with praying to God, that it didn’t give up Khevi and were its protector in all troubles forever. (Kazbegi, 1976, p. 284)

Kazbegi uses some samples of folklore oral speech as well. Deep traces of folklore oral speech are observed in the story of Kazbegi "Elguja". The story has a political nature and relies on the historic facts of the Mtiuleti uprising in 1804. In times of High Commissioner Pavle Tsitsianov the rebels conquered Military Road of Georgia and got in touch with Aleksandre Batonishvili exiled to Iran, whose goal was to ascend the throne of Georgia. Al. Kazbegi describes attitude of people towards Russia and its political interests in this way:

Georgia is under protection of Russia! This voice was like a strike, for we wished protection of Russia and suddenly we became its serf... After this they agreed that they would block the road for Russian troops, which were to pass in ten days, at Pasanauri narrow places, so that they cannot go further and go back. They would agree with the Mokheves that they block Dariali Gorge and no one could pass through. (Kazbegi, 1976, p. 113) 
The characters of the story, Elguja and SvimonChopikashvili are real persons. There is a legend in Khevi that ElgujaPashateli kidnapped a woman, in the story Circassian woman Mzagho from the family of Chopikashvili and the pursuers took her life. About Elguja there exist folkloric poems in Khevias well. It is noteworthy that many of them come from the text of the story. Kazbegi's characters are in selfless love with each other, their final goal is to start a family.

Here we should pay attention to the most important issue in Kazbegi's works. The characters of his stories are children of different nations in Caucasus, they differ from each other with their ethnicity as well as their religion. Kazbegi puts stress on different religions and ethnicity in his works, but when he speaks of universal values, like friendship, love, fight for freedom, there are no borders between the characters, they serve the same idea.

Kazbegi often uses folklore legends and proverbs in "Elguja”. Their use in Kazbegi's works is synthesized with explanation of some traditions. There are similar examples of it in the world literature. We read in the text: "- -you are right, you are right! Let us die, if the day of day has come. A man is born once and he should die once” (Kazbegi, 1976, p. 66). The mountaineers address sick Elguja in this way and thus they prove their bravery against injustice. Or "it should have been among those people this way, 'where a man with scars is better' and where a normal woman wouldn't marry the man, who had no scars on his face” (Kazbegi, 1976, p. 67).

In the work we can see the institute of sworn brotherhood. The Mokheves and the Mtiulis swear brotherhood before fight against Russian troops, "that all of them become one and act in the name of the one, and the one sacrifices for all and all—for the one".

But this oath was not necessary, they considered it their duty to help each other and to sacrifice oneself for each other. It should have been so in those people, where together with mother's milk they absorbed and instilled hatred and disgust towards traitor of their friends. These are people, whose fairytales or poems were on this topic and instilled this strong viewpoint” (Kazbegi, 1976, pp. 118-119).

Al. Kazbegi described immortal face of GinjaKhuleli, public speaker of Khevi. Some of the poems he had written down are used in the work. "The writer knew him personally and he wrote down his poems too, in particular, the famous folk mourning poem about King Erekle 'Resurrect, great hero'” (Chavleishvili, 1985, p. 82). "So, GinjaKhuleli is a real person, he lived in the second part of the 19th century and in 1881, when 'Elguja' was being written, he was old. Ginja was a great connoisseur and masterful performer of traditional literature" (Chikovani, 1952, p. 160).

Kazbegi characterizes GinjaKhuleli in the following way:

With Svimon, old Ginja was sitting... He was a famous panduri (Georgian string instrument) player in the mountains and a witty poet full of feelings, therefore, everybody respected him and he was a desirable guest, sweet-voiced, full of elevated feeling, every time he touched the cords Ginja made panduri produce such sound that it made a man's heart sink, gave the creeps and made sweat. (Kazbegi, 1976, p. 156)

In the narrative we can see disruption of the community, though the community is doing its best to maintain old traditions. All contentious issues are decided by the oldest people of the community and they pass a logic verdict. Judgment of the sworn foe and reconciliation is described in an interesting way. The issue of Elguja and Svimon Chopiashvili is reviewed by the community and when they see that Gagi was not murdered by Elguja, Chopikashvili shouldn't revenge. The council takes into consideration that Mzagho was not kidnapped and she went with Elguja voluntarily. In this case it is obvious that the community follows democratic and human principles. Though, the community requests fulfillment of the decision: 
That Gagi fell from the cliff doesn’t mean that Elguja murdered him and you shouldn't seek revenge for it. Instead Elguja's lands will be confiscated and be given to SvimonChopikashvili... Svimon, in turn, will pay for medical treatment of Elguja. Elguja's relatives, in presence of the community men, should come with a bull and bear for plea at Gagi's grave. The woman should stay with Svimon as bought, and if Elguja wishes to take her, he should pay a penaltywith 40 cows. After this the families Elguja and Svimon should become brothers, good neighbors and they must love each other.(Kazbegi,1976, p. 79)

The scenes of some traditions are described in the story, funeral mourning, and loud lamentation of the dead person. After death of sick Svimon Chopikashvili.

The dead was washed, dressed in his best clothes, shaved and taken to "the rooms". The mourners and grieving relatives were around him, but they were standing near so that a person could go between the mourners and the dead person... These were mostly women and old women, who had shawls on their shoulders,tumbled their hair and with rolled up sleeves they were ready to lament. The women of the village... came in crying in a specific style of crying characteristic of the mountains...This event continued for seven days. Any of old women in the house took the gun from the chest of the dead, leaned over it and said about the life of the dead in poems, told the other people his life. From time to time the other mourners sang with her and cried with worried voice.Together with the name of the dead, the names of those dead who had ever done any noteworthy work and deserved a name of a brave manare never forgotten.(Kazbegi, 1976, p. 166)

Kazbegi describes the traditions and the customs of Mokheves with great accuracy.

\section{Conclusion}

"Elguja" of Al. Kazbegi can be referred to as the novels where the action is developed on the background of love between MokheveElguja and Circassian woman Mzagho, friendship and heroism. The landscape is a background for expression of the spiritual world of the heroes. The writer uses folkloric material in order to show the customs and traditions of the mountaineers.

In "Khevisberi Gocha", Al. Kazbegi describes ritual scenes and traditions characteristic for life of Mokheves on the basis of the samples of folklore oral speech and legends. The story has psychological character and the author tells us the adventures of the heroes with deep tragedy. As we have already seen, Kazbegi uses folklore material in his ethnographic and autobiographic stories.

Despite the fact that several scientific works are dedicated to study of Kazbegi's literary heritage, many other issues are to be discussed in connection with modern time in new perspective and approaches.

\section{References}

Chavleishvili, T. (1985). Creative history of Kazbegi's “Elguja”. Tbilisi: Publishing House "Science”.

Chikovani, M. (1952). History of Georgian folkloric literature. Tbilisi: Publishing House Of Scientific Methodical Cabinet.

Kazbegi, A. (1976). Stories. Tbilisi: Publishing House “Nakaduli”.

Vardoshvili, E. (2010).Poetic coincidences. Tbilisi: Polygraphic Center “Barton”. 